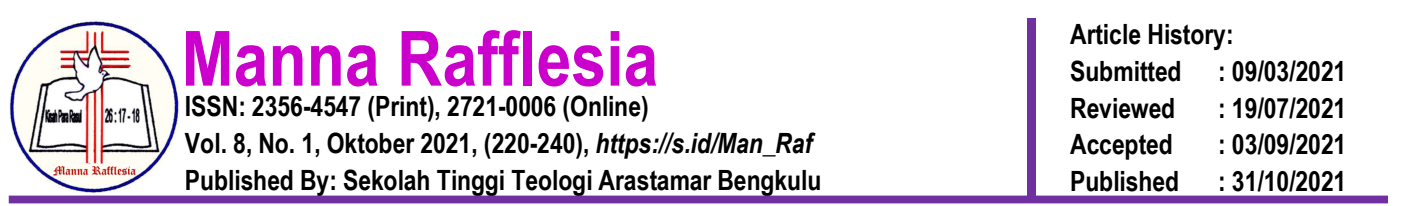

\title{
PENGAJARAN TENTANG MAKNA EGO EIMI BERDASARKAN INJIL YOHANES DAN IMPLIKASINYA BAGI UMAT KRISTEN
}

\author{
Marthen $\left.\mathrm{Mau}^{1} *\right)$ \\ Sekolah Tinggi Teologi Injili Arastamar Ngabang ${ }^{1}$ \\ *)Email Correspondence: marthenluthermau@gmail.com
}

\begin{abstract}
Egô eimi means a firm statement made by Jesus Christ to the people that he is the living God. Jesus is the living God, so He is not a madman and a liar as people think. The purpose of this study is that every believer or believer must admit that Jesus is God. The reason for the appearance of the statement in the Gospel of John is because of the doubts of mankind about His personality and existence. This study uses a qualitative methodology with an exegesis approach. Qualitative research methodology is an in-depth analysis approach using inductive reasoning analysis techniques to understand a problem subjectively. The purpose of this research using qualitative methodology is to narrate about of John gospel. So, this study attempts to describe what is in accordance with the text in the Gospel of John, using exegesis studies because the main focus is to narrate the text of God's word about the seven statements of. The result of the research is Jesus Christ as God who has come down from heaven like a human to save mankind.
\end{abstract}

Keywords: The meaning of egô eimi; The Gospel of John; Christians Faith

Abstrak: Egô eimi artinya suatu pernyataan tegas yang dikemukakan oleh Yesus Kristus kepada orang banyak bahwa diri-Nya adalah Allah yang hidup. Yesus adalah Allah yang hidup, maka Dia bukan seorang gila dan pembohong seperti yang disangkakan oleh manusia. Tujuan penelitian ini ialah setiap orang yang percaya atau beriman harus mengakui bahwa Yesus adalah Allah. Alasan munculnya

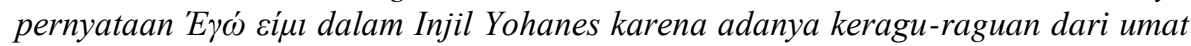
manusia terhadap kepribadian dan eksistensi-Nya. Penelitian ini menggunakan metodologi kualitatif dengan pendekatan eksegesis. Metodologi penelitian kualitatif merupakan suatu pendekatan analisis mendalam dengan memakai teknik analisis penalaran induktif untuk memahami suatu masalah secara subyektif. Tujuan penelitian menggunakan metodologi kualitatif ialah untuk menarasikan mengenai

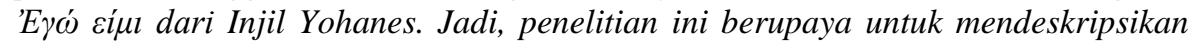
apa adanya sesuai dengan teks di dalam Injil Yohanes, dengan menggunakan studi eksegesis karena fokus utama adalah menarasikan teks firman Tuhan tentang

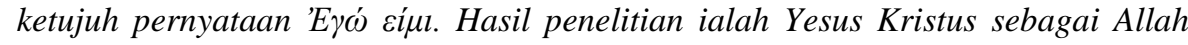
yang telah turun dari surga menyerupai seperti manusia untuk menyelamatkan umat manusia.

Kata Kunci: Makna egô eimi; Injil Yohanes; Iman Kristen.

\section{PENDAHULUAN}

Pengajaran tentang egô eimi (Yun. 'E $\gamma \omega ́$ cífı) adalah pernyataan tegas Yesus

Kristus dalam Injil Yohanes yang menunjukkan bahwa diri Yesus sebagai Allah 
yang hidup, yang sama derajatnya dengan Allah Bapa. Di dalam Injil Yohanes istilah 'E $\gamma \omega ́$ (egô) yang bertalian dengan promina persona kasus nominatif atau subjek disebutkan sebanyak 132 kali, sedangkan cífı (eimi) di dalam Injil Yohanes disebutkan sebanyak 430 kali. Dasar munculnya istilah egô eimi dalam Injil Yohanes karena adanya keragu-raguan terhadap pribadi dan eksistensi Yesus Kristus. Karena itu, pernyataan egô eimi oleh Yesus Kristus untuk memberikan pernyataan secara tegas kesempurnaan-Nya. Pernyataan egô eimi dalam Injil dapat ditemukan dalam Yohanes 6: 35 (Akulah roti hidup), Yohanes 8: 12 (Akulah terang dunia), Yohanes 10: 7, 9 (Akulah pintu), Yohanes 10: 11 (Akulah gembala yang baik), Yohanes 11: 25-26 (Akulah kebangkitan dan hidup), Yohanes 14: 6 (Akulah jalan dan kebenaran dan hidup), dan Yohanes 15: 1, 5 (Akulah Pokok Anggur yang benar).

Pernyataan Yesus tentang egô eimi merupakan pernyataan sakral Yesus Kristus. Pada prinsipnya Injil Yohanes berbeda pemikiran dengan Injil sinoptik (Matius, Markus dan Lukas). Injil Yohanes tidak menceritakan mengenai kelahiran Yesus, sedangkan Injil Sinoptik memulai narasi dari genalogi Yesus Kristus. Tujuan utama penulisan Injil Yohanes ialah supaya setiap orang mengaku dan meyakini bahwa Kristus Yesus sebagai Mesias, Anak Allah Mahatinggi dan melalui Yesus dapat memeroleh hidup kekal (Yoh. 20: 31). Oleh karena itu Injil Yohanes adalah kitab yang khusus membicarakan eksistensi dan karya Yesus Kristus. ${ }^{1}$ Selain itu juga Injil Yohanes menjadi dasar dalam menghadapi pengajaran gnostik. ${ }^{2}$ Selain itu ada yang berpendapat bahwa tujuan penulisan Injil

${ }^{1}$ Leon Morris, Teologi Perjanjian Baru (Malang: Gandum Mas, 2014), 311.

2 F. Evertt Harrison, John The Gospel of Faith (Chicago: Moody Press, 1962), 10. 
Yohanes untuk melawan Yudaisme yang diajarkan di sinagoge dan melengkapi Injil Sinoptik. $^{3}$

Pernyataan egô eimi oleh Yesus bagi orang Yahudi menunjukkan bahwa Yesus adalah orang gila dan pembohong. ${ }^{4}$ Bahkan pada saat ini ada banyak orang yang menyetujui bahwa Yesus adalah Allah seperti dikutip oleh Clive Staples Lewis yang menerima Yesus sebagai guru moral yang agung, tetapi tidak percaya bahwa Yesus adalah Allah. ${ }^{5}$ Menanggapi hal tersebut maka perlu memahami pernyataan egô eimi dalam Injil Yohanes sebagai pernyataan sikap Yesus untuk menunjukkan sifat ke-Allah-an-Nya kepada manusia.

\section{METODE}

Penulis menggunakan metodologi penelitian kualitatif, $^{6}$ dengan pendekatan eksegesis. Metode kualitatif merupakan suatu pendekatan analisis mendalam dengan memakai teknik analisis penalaran induktif untuk memahami suatu masalah secara subyektif. ${ }^{7}$ Menggunakan metodologi kualitatif bertujuan untuk menarasikan ungkapan egô eimi dalam Yohanes 6: 35, 8: 12, 10: 7-9, 10: 11, 11: 25-26, 14: 6 dan 15:1-5 serta mendeskripsikan konsep egô eimi sesuai dengan teks di dalam Injil Yohanes. Penggunaan pendekatan studi eksegesis karena fokus utama adalah menarasikan teks firman Tuhan tentang ketujuh pernyataan egô eimi secara khusus dalam studi kata dan makna dalam konteks ayat-ayat tentang egô eimi.

\footnotetext{
3 Edwin A Blum, "John. The Bible Knowledge Commentary" (Wheaton, IL: Victor Books, 1985), 10.

4 Daniel Nugroho, "Mengulas Lengkap Siapa Pribadi Yesus," www.danielnugroho.com, Faith, 9 Januari 2021, https://www.danielnugroho.com/faith/mengulas-lengkap-siapa-pribadi-yesus/.

5 Nugroho.

6 Sonny Eli Zaluchu, "Strategi Penelitian Kualitatif dan Kuantitatif Di Dalam Penelitian Agama," Evangelikal: Jurnal Teologi Injili dan Pembinaan Warga Jemaat 4, no. 1 (2020): 28-38, https://doi.org/10.46445/ejti.v4i1.167.

7 Arif Yupiter Gulo, "Cerdik seperti Ular dan Tulus seperti Merpati: Berdasarkan Matius 10:16b," Manna Rafflesia 7, no. 1 (31 Oktober 2020): 118, https://doi.org/10.38091/man_raf.v7i1.129.
} 


\section{HASIL}

Pernyataan egô eimi sesungguhnya memiliki makna bahwa Yesus sedang menunjukkan eksistensi sebagai Manusia dan Allah sejati. Hasil penelitian menunjukkan bahwa Yesus adalah Tuhan dan Juruselamat bukan seorang gila dan pembohong. Makna pernyataan egô eimi menunjukkan bahwa setiap manusia yang sungguh-sungguh percaya dan menerima Yesus sebagai satu-satunya jalan keselamatan memperoleh hidup kekal di dalam Kerajaan Surga yang abadi. Selanjutnya hasil penelitian ini menunjukkan bahwa Yesus hadir ke dalam dunia untuk memproklamirkan berita kedatangan Kerajaan Allah (Mrk. 1: 14-15) dan berita yang diproklamirkan adalah kebenaran. Hasil penelitian mengenai egô eimi menunjuk pada proklamasi Yesus adalah kebenaran. Yesus mengajarkan dan memproklamirkan kebenaran sebab Yesus sebagai pintu masuk ke dalamnya, karena Yesus adalah kebenaran itu.

\section{PEMBAHASAN}

Pemahaman konsep egô eimi dijelaskan dalam beberapa perkataan Yesus dalam Injil Yohanes, yaitu: Akulah roti hidup (Yoh. 6: 35), Akulah terang dunia (Yoh. 8: 12), Akulah Pintu (Yoh. 10: 7, 9), Akulah gembala yang baik (Yoh. 10: 11), Akulah kebangkitan dan hidup (Yoh. 11: 25-26), Akulah jalan dan kebenaran dan hidup (Yoh. 14: 6) dan Akulah Pokok Anggur yang benar (Yoh. 15: 1, 5).

\section{Akulah Roti Hidup (Yoh. 6: 35)}

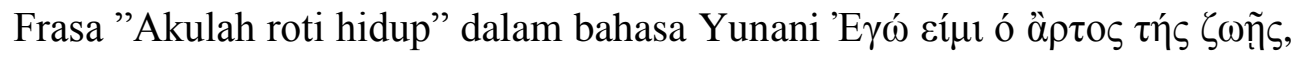
(egô eimi ho artos tēs zōess). Frasa tersebut menunjukkan bahwa Yesus menyebutkan diri-Nya sebagai makanan yang memberi hidup. Kata roti dalam 
bahasa Yunani òj $\tau o \varsigma$ yang berarti roti; makanan. ${ }^{8}$ Ungkapan roti dalam teks Yohanes 6: 35 menggunakan kata sandang ó òp bahwa kata 'roti' di dalam teks tersebut bukan roti buatan manusia yang dijual-

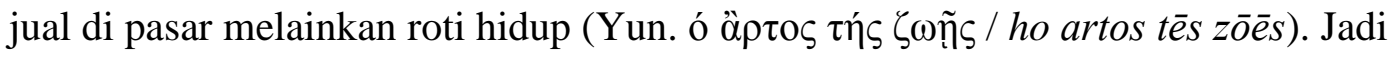
Yesus menyebutkan diri-Nya sebagai roti yang memberi kepuasan kepada orang percaya. Guthrie dkk. menarasikan bahwa roti hidup merupakan ungkapan perumpamaan yang berarti Yesus memberi hidup kepada orang-orang percaya yang menyerahkan dirinya pada Yesus Kristus sebagai Juruselamat dunia. ${ }^{9}$ Tuhan Yesus Kristus memberikan hidup kekal kepada manusia ketika manusia percaya sungguh-sungguh kepada-Nya.

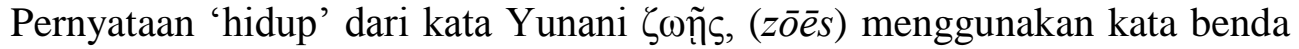
kasus genetif, yang artinya hidup (jasmaniah), hidup (baru), hidup (kebangkitan) dan hidup (kekal). ${ }^{10}$ Pemahaman $\zeta \omega n ̃ ̄ s, ~(z \bar{e} \bar{s})$ di dalam teks Yohanes 6: 35 menunjuk pada hidup kekal bukan hidup secara jasmaniah. Jadi, hidup kekal diberikan oleh Yesus karena mampu menghidupkan umat manusia ketika sungguh-sungguh percaya kepada-Nya. Selanjutnya frasa "barangsiapa datang

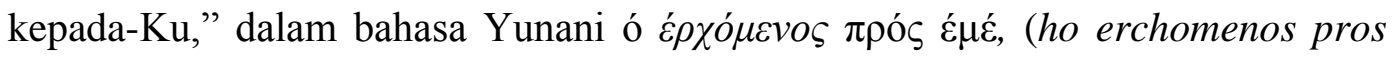
me). Kata é $\rho \chi o ́ \mu \varepsilon v o \varsigma$ (erchomenos) menggunakan kata kerja kasus nominatif

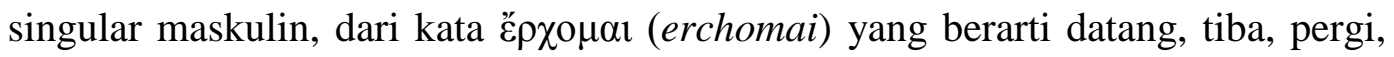
pergi bersama, sampai, berjalan, menjadi, mendatangkan, membawa, akan datang dan muncul. Kata tersebut diikuti oleh kata sandang ó (ho) dan kata depan (preposition) kepada-Ku (pros me), maka dapat diartikan sebagai orang yang

${ }^{8}$ Hasan Sutanto, Perjanjian Baru Interlinear Yunani-Indonesia dan Konkordansi (PBIK) Jilid II, vol. 2 (Jakarta: LAl, 2014), 109.

${ }^{9}$ Guthrie, Motyer, dan Stibbs, Tafsiran Alkitab Masa Kini 3 Matius-Wahyu (Jakarta: Yayasan Bina KAsih/OMF, 2001), 287.

10Sutanto, Perjanjian Baru Interlinear Yunani-Indonesia dan Konkordansi (PBIK) Jilid II, 2:120. 
datang kepada Yesus. Frasa "ia tidak akan lapar lagi," dalam bahasa Yunani ov́ $\mu$ ń $\pi \varepsilon \imath$ óoๆ (ou me peinase). Frasa ov́ $\mu$ 门́ (ou me) artinya pasti tidak ${ }^{11}$ dan kata 'lapar' dari kata $\pi \varepsilon ı$ óoๆ (peinase) menggunakan kata kerja dengan kasus aorist aktif orang ketiga tunggal, dari kata dasar $\pi \varepsilon 1 v \alpha ́ \omega$ (peinao) artinya merasa lapar. ${ }^{12}$ Dengan demikian kata tersebut memiliki makna tindakan yang telah terjadi secara terus-menerus ketika dialami seseorang. Jika diartikan bersama kata ov́ $\mu$ (ou me) maka frasa "ia tidak akan lapar lagi," berarti pada waktu dulu ia pasti tidak merasa lapar secara terus-menerus ketika datang kepada Yesus Kristus.

Frasa "barangsiapa percaya kepada-Ku," dalam bahasa Yunani ó $\pi \imath \sigma \tau \varepsilon v ́ \omega v$

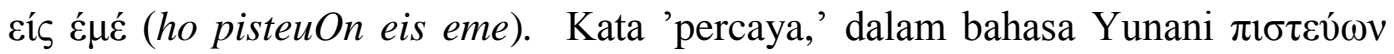
(pisteuon) menggunakan kata kerja present aktif kasus nominatif singular maskulin dari kata $\pi \_\tau \varepsilon v ́ \omega$ (pisteuo) artinya percaya, mempunyai iman kuat, yakin dan mempercayakan. ${ }^{13}$ Pernyataan ini menunjukkan bahwa orang yang percaya kepada Yesus harus kuat atau teguh pendiriannya bahkan pada waktu sekarang harus terus-menerus percaya kepada Yesus Kristus. Laia menuliskan kata 'percaya' merujuk pada sebuah keyakinan yang tahan dalam pencobaan, penderitaan, pengujian, tidak hanya percaya tetapi sungguh-sungguh percaya kepada Allah di dalam Yesus Kristus tanpa dibutuhkan bukti-bukti real seperti Abraham. ${ }^{14}$ Selanjutnya frasa "ia tidak akan haus lagi," dalam bahasa Yunani ov́

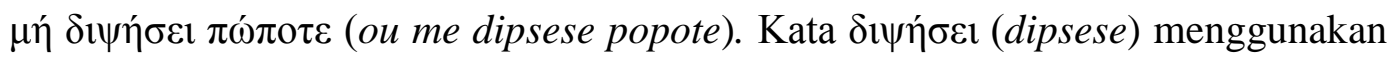

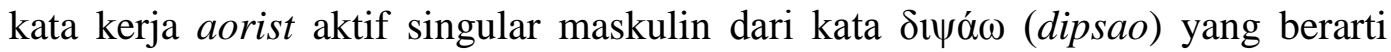

11 Hasan Sutanto, Perjanjian Baru Interlinear Yunani-Indonesia dan Konkordansi Perjanjian Baru (PBIK) Jilid I, vol. 1 (Jakarta: LAl, 2010), 514.

12 Sutanto, Perjanjian Baru Interlinear Yunani-Indonesia dan Konkordansi (PBIK) Jilid II, 2:586.

13 Sutanto, 2:599.

14 Kejar Hidup Laia, "Makna Injil Berdasarkan Roma 1: 16-17 Dan Implementasinya Bagi Gereja Masa Kini," Manna Rafflesia 7, no. 1 (2020): 1-21, https://doi.org/10.38091/man_raf.v7i1.133. 


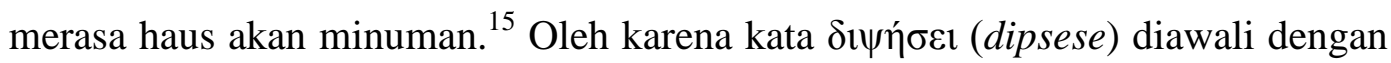
kata ov́ $\mu \eta ́$ (ou me) dan diakhiri dengan kata $\pi \omega ́ \pi o \tau \varepsilon$ (popote) maka pernyataan di dalam teks Yohanes 6: 35 dapat diartikan bahwa pada waktu dulu orang pasti tidak akan terus-menerus merasa haus lagi ketika ia percaya kepada Yesus Kristus. Berdasarkan penjelasan tersebut Yesus terus-menerus berkata kepada para murid sebagai pemberi dan pemelihara kehidupan umat-Nya (bdk. Yoh. 6: 53), ${ }^{16}$ bahkan siapa yang datang kepada Yesus pasti dijamin kepuasannya dari kelaparan dan kehausan secara batiniah. Setiap orang yang datang kepada Yesus pasti menerima kebahagiaan batiniah (bdk. Mat. 5: 6). Secara prinsip Yesus Kristus menjamin dengan sempurna untuk memberikan kehidupan kekal di dalam Kerajaan Surga bagi orang-orang yang terus-menerus menyembah pada Yesus Kristus.

\section{Akulah terang dunia (Yoh. 8: 12)}

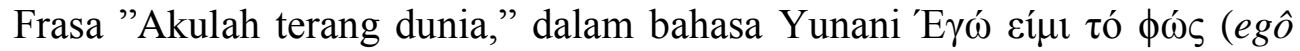
eimi to phos). Kata $\phi \omega ́ \varsigma$ (phos) menggunakan kata benda kasus nominatif artinya

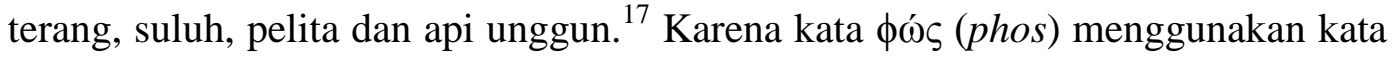
benda kasus nominatif, maka dapat diartikan Yesus adalah terang. Kata 'dunia'

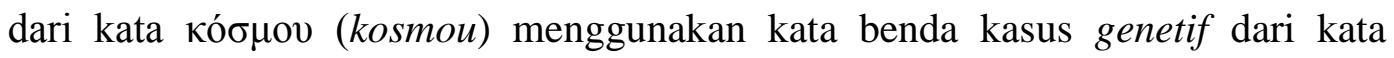

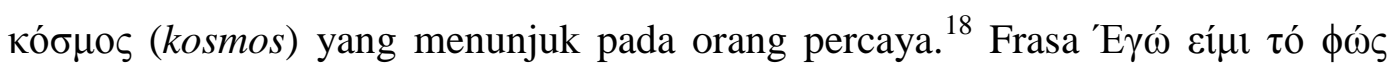
(egô eimi to phos) dapat dipahami bahwa Yesus adalah terang bagi manusia atau

${ }^{15}$ Sutanto, Perjanjian Baru Interlinear Yunani-Indonesia dan Konkordansi (PBIK) Jilid II, 2:504.

${ }^{16}$ Donald C. Stamps, Alkitab Penuntun Hidup Berkelimpahan (Jakarta: Lembaga Alkitab Indonesia, 2008), 1713

17 Sutanto, Perjanjian Baru Interlinear Yunani-Indonesia dan Konkordansi (PBIK) Jilid II, 2:755.

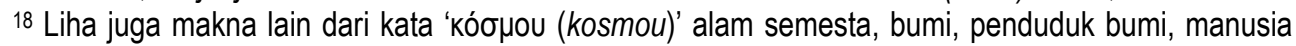
dan malaikat, masyarakat, segala yang ada di bumi, atau orang yang percaya. Dunia juga dapat menunjuk musuh Allah, masyarakat yang sekular, sistem yang jahat, kesenangan duniawi, harta di dunia, kekuatiran dan penderitaan di dunia (Lih. Sutanto, 2:458.). 
orang percaya yang hidup di dalam dunia. Yesus menegaskan bahwa diri-Nya sebagai Terang, Sumber Terang, dan Terang yang menciptakan dunia (Yoh. 1: 410). ${ }^{19}$ Yesus sebagai sumber terang bagi dunia sebab Dia terlebih dahulu hidup dari Abraham (bdk. Yoh. 8: 5). Jadi kegelapan dapat dinetralisir oleh cahaya terang dan secara figuratif terang Kristus menerangi kegelapan dunia yang disebabkan oleh kekuatan dosa.

Yesus Kristus memiliki kuasa yang tidak terbatas untuk menerangi manusia. Karena itu, siapa saja yang mengiringi Kristus Yesus tentu akan hidup di dalam terang Kristus yang ajaib. Stamps menjelaskan Yesus sebagai terang yang memberi hidup (Yoh. 1: 9), sehingga berkuasa untuk menolong setiap orang untuk keluar dari belenggu dosa. ${ }^{20}$ Frasa "barangsiapa mengikut Aku," dalam bahasa

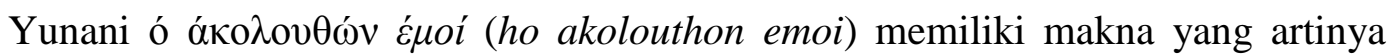
pada waktu sekarang orang yang mengikuti Yesus secara terus-menerus dapat memeroleh terang yang memberi hidup kekal. ${ }^{21}$ Jadi Yesus adalah sang Penerang dalam kegelapan, Pemberi terang bagi setiap orang yang berada dalam kegelapan, dan hidup kekal bagi setiap orang yang mengikut Yesus secara terus-menerus setelah meninggalkan kegelapan dosa. Brickner menuliskan pernyataan "Akulah terang dunia" merupakan salah satu bukti bahwa Yesus menyatakan diri sebagai Allah yang memberi hidup kekal (Yun. zoes) kepada setiap orang yang meninggalkan kegelapan dosa (Yun. skotia). ${ }^{22}$ Berdasarkan ulasan di atas dapat dikonklusikan bahwa Yesus sebagai terang bagi manusia di dunia yang hidup di

19 Deflit Dujerslaim Lilo, "Presuposisi dan Metode Yesus dalam Menyampaikan Pendapat: Sebuah Pedoman bagi Para Akademisi," BIA': Jurnal Teologi dan Pendidikan Kristen Kontekstual 2, no. 1 (26 Juni 2019): 121, https://doi.org/10.34307/b.v2i1.86.

20 Stamps, Alkitab Penuntun Hidup Berkelimpahan, 1718.

21 Kata ákołouӨúv (akolouthon) menggunakan kata kerja present active nominative singular masculine (Lih. Sutanto, Perjanjian Baru Interlinear Yunani-Indonesia dan Konkordansi Perjanjian Baru (PBIK) Jilid I, 1:755.)

22 David Brickner, Christ in the Feast of Tabernacles (Chicago, Illinois: Moody Publishers, 2006), 156. 
dalam dosa. Setiap orang yang sudah yakin menerima hidup kekal harus siap diutus oleh Kristus untuk membawa terang bagi manusia yang masih tinggal di dalam kegelapan dosa (Mat. 5: 14).

\section{Akulah Pintu (Yoh. 10: 7, 9)}

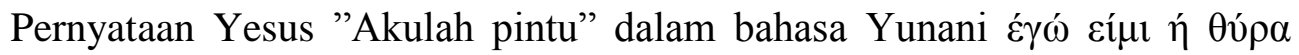

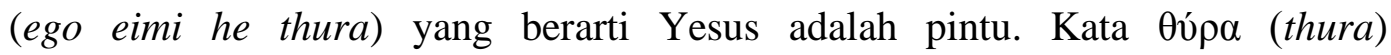
menggunakan kata benda kasus nominatif singular feminin yang artinya kata

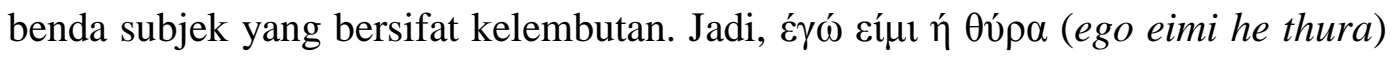
yang artinya Yesus adalah pintu itu ke domba-domba atau untuk domba-domba ( $\tau \omega ́ v \pi \rho o \beta \alpha ́ \tau \omega v$ (ton probaton). Pernyataan "Akulah pintu ke domba-domba itu"

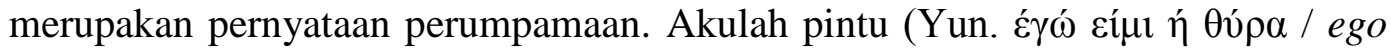
eimi he thura) merupakan perumpamaan yang menjadi kebiasaan di timur tengah bahwa kandang domba berupa tanah berpagar kecil untuk melindungi kawanan pada waktu malam hari dari binatang buas atau sebuah bangunan rendah yang terbuka ke arah halaman dan hanya ada satu pintu masuk, gembala duduk di dekat pintu masuk, sehingga bisa menjadi "gembala" dan "pintu." 23 Pertemuan gembala dan domba hanya melalui satu pintu karena gembala telah menunggu di pintu masuk ke kandang.

Penjelasan selanjutnya pada frasa "Aku berkata" pada ayat ke 7 dalam bahasa Yunani $\lambda \varepsilon ́ \gamma \omega$ (lego) yang artinya berkata. ${ }^{24}$ Kata $\lambda \varepsilon ́ \gamma \omega$ artinya saya berkata secara terus-menerus. Pada konteks ayat tersebut menunjukan kepada Yesus yang

\footnotetext{
${ }^{23}$ Candra Gunawan Marisi, "Analisis Teologis Mengenai Tugas Dan Tanggungjawab Gembala Yang Baik Menurut Yohanes 10: 1--18 Dan Penerapannya Bagi Gembala Masa Kini," Real Didache Jurnal Teologi dan Pendidikan Agama Kristen 4, no. 2 (2019): 46.

24 Lihat arti lain dari $\lambda \varepsilon ́ \gamma \omega$ (lego) yaitu mengucapkan, menceritakan, mengungkapkan (secara lisan atau tertulis), dimaksudkan, sebagai berikut, berpesan, menanyakan, menjawab, memerintah, menegaskan, menyatakan, memberitakan, memberitahukan, melaporkan, memanggil, menyebut dan berarti (Sutanto, Perjanjian Baru Interlinear Yunani-Indonesia dan Konkordansi (PBIK) Jilid II, 2:452.)
} 
berkata secara terus-menerus. Selanjutnya kata ganti orang 'kamu' yang dipakai di

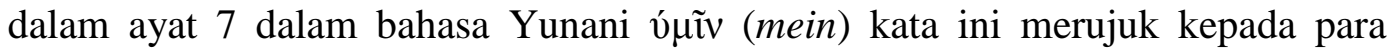
murid Yesus Kristus. Selanjutnya "Aku berkata kepada kamu" dari frasa $\lambda \varepsilon \dot{\gamma} \omega$ v́ñ̃v (lego umin) hal tersebut menunjuk bahwa Yesus berkata secara terusmenerus kepada para rasul. ${ }^{25}$ Pendapat tersebut dapat diartikan sebagai sebuah kepastian bagi yang datang melalui Yesus, jiwa diselamatkan pada masa mendatang. Jadi, kata 'masuk' dan 'keluar' merupakan dua kata kerja yang sangat penting, Sumiwi melukiskan dua kata kerja "masuk" dan "keluar" merupakan aktivitas dari domba-domba pada setiap harinya. ${ }^{26}$ Pernyataan menemukan padang rumput berarti domba-domba mencari makanan di padang rumput yang hijau sebab tanpa menemukan rumput, maka domba-domba pasti mengalami kelaparan. Tuhan Yesus mengilustrasikan diri-Nya sebagai 'pintu' karena itu, setiap orang yang masuk melalui Yesus akan mengalami pertumbuhan rohani yang tidak akan pernah layu sebab Dialah satu-satunya pintu bagi domba-

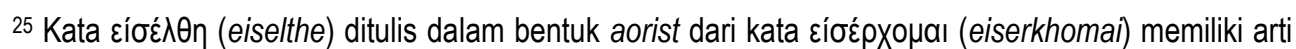

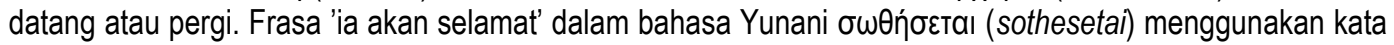
kerja indikatif future pasif orang ke-3 tunggal dari kata $\sigma \varphi \zeta \omega$ (sozo) yang berarti menyelamatkan dan menyembuhkan (Hasan Sutanto, Perjanjian Baru Interlinear dan Konkordansi Jilid 2 (Jakarta: Lembaga

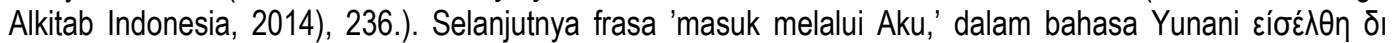

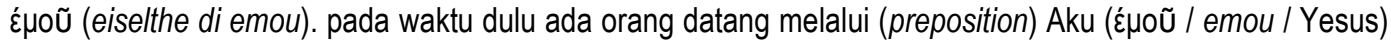

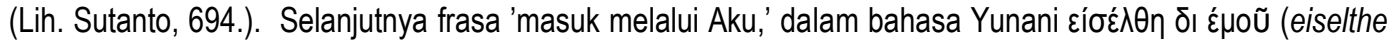
di emou). pada waktu dulu ada orang datang melalui (preposition) Aku (غ́noũ / emou / Yesus) (Lih. Sutanto,

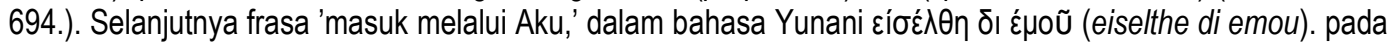

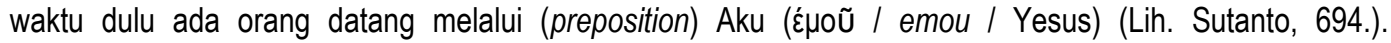

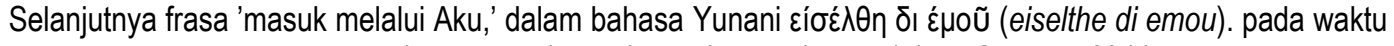
dulu ada orang datang melalui (preposition) Aku (દ́noũ / emou / Yesus) (Lih. Sutanto, 694.)

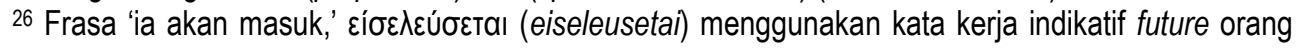

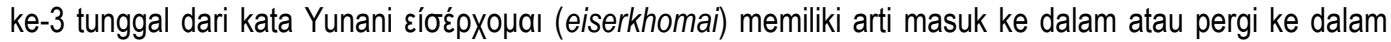
(Lih.Sutanto, Perjanjian Baru Interlinear Yunani-Indonesia dan Konkordansi (PBIK) Jilid II, 2:236.). Kata

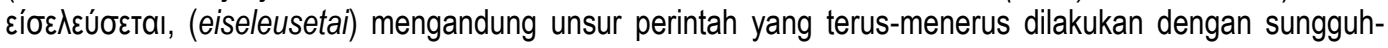

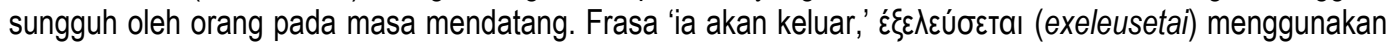
kata kerja indikatif future orang ke-3 tunggal dari kata (Lih.Sutanto, 2:270.). Asih Rachmani Endang Sumiwi, "Gembala Sidang Yang Baik menurut Yohanes 10:118," HARVESTER: Jurnal Teologi dan Kepemimpinan Kristen 4, no. 2 (2020): 74-93, https://doi.org/10.52104/harvester.v4i2.16.
} 
domba. ${ }^{27}$ Dari penjelasan di atas dapat diformulasikan bahwa Yesus berkata secara terus-menerus kepada para murid-Nya tentang mengumpamakan diri-Nya sebagai pintu untuk orang-orang yang datang melalui Dia. Karena jikalau ada orang yang datang melalui Dia, maka dia pasti diselamatkan dan Yesus Kristus akan memelihara hidupnya di dunia hingga menuju kehidupan surga yang abadi.

\section{Akulah gembala yang baik (Yoh. 10: 11)}

Sebuah pernyataan Kristus yang sangat tepat untuk mematahkan gembala palsu ketika mengajarkan pengajaran palsu yakni "Akulah gembala yang baik,"

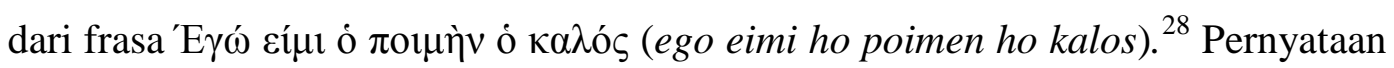
Aku adalah Gembala yang baik berarti Yesus memiliki kualitas moral yang menguntungkan atau berguna bagi domba-domba-Nya bahkan Yesus membedakan diri-Nya dengan para gembala palsu. Murray menyatakan bahwa kata $\kappa \alpha \lambda \mathrm{s}$, kalos yang berarti otentik, unik, satu-satunya, atau benar. ${ }^{29}$ Frasa gembala yang baik dapat diartikan bahwa Yesus sebagai gembala yang benar sehingga perlu menjadi teladan. Yesus sebagai Gembala yang benar, sehingga mengajarkan pengajaran yang benar kepada para pengikut-Nya. Oleh karena Yesus sebagai gembala yang benar, maka pasti Yesus menuntun setiap orang yang

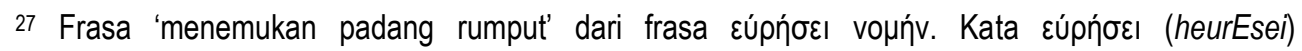
menggunakan kata kerja indikatif future orang ke-3 tunggal yang diartikan akan menemukan (Lih.Sutanto, Perjanjian Baru Interlinear Yunani-Indonesia dan Konkordansi (PBIK) Jilid II, 2:546.). Kata ini dari kata

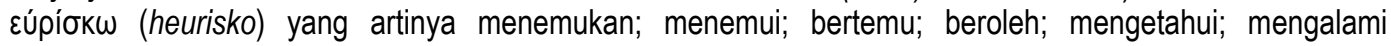

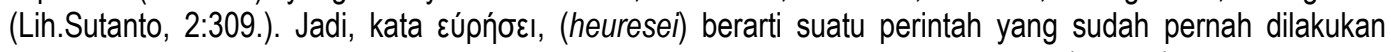
tetapi secara terus-menerus dilakukan pada masa mendatang. Kata vouńv (nomen) berarti padang rumput/makanan (Lih.Sutanto, 2:546.). Kata vouńv (nomen) menggunakan kata benda akusatif tunggal feminin, yang artinya suatu objek yang sifatnya lembut. Karena itu, kata vouńv (nomen) dari kata vouń (nome) yang artinya padang rumput; makanan (ternak) (Lih.Sutanto, 2:504.). Sumiwi, "Gembala Sidang Yang Baik menurut Yohanes 10:1-18."

28 Kata 'baik' dari kata ka內os menggunakan kata sifat, maka kata ini dalam pengertian moral, kualitas, yang menguntungkan, yang menyenangkan, yang berguna, atau cocok (Lih.Sutanto, Perjanjian Baru Interlinear Yunani-Indonesia dan Konkordansi (PBIK) Jilid II, 2:398.)

29 G. R. Beasley Murray, John Volume 36 (Dallas, Texas: Word Books, Publisher, 2002), 170. 
percaya kepada-Nya. ${ }^{30}$ Dalam teks Yohanes 10: 11 menjelaskan bahwa Yesus dapat membedakan diri-Nya dengan gembala upahan. Yesus bukanlah seorang gembala upahan karena tujuan kedatangan-Nya ke dalam dunia demi memberikan hidup-Nya bagi umat manusia supaya mereka memiliki hidup yang abadi di dalam Kerajaan-Nya yang abadi.

\section{Akulah Kebangkitan Dan Hidup (Yoh. 11: 25-26)}

Sebuah pernyataan yang meyakinkan bagi khalayak ramai, termasuk kepada Maria dan Marta saudara Lasarus; saat Yesus hendak membangkitkan Lazarus ialah "Akulah kebangkitan dan hidup." Kata kebangkitan menurut Perjanjian Baru merupakan pengajaran Firman Tuhan karena tanpa kebangkitan Yesus, maka tidak akan ada kebangunan rohani. Jadi kebangkitan Tuhan Yesus merupakan konfirmasi sentral di dalam firman Tuhan agar setiap orang yang percaya kepadaNya beroleh kehidupan yang kekal. ${ }^{31}$ Kehidupan kekal yang dapat dipahami dalam bagian ini adalah kehidupan kehidupan kekal yang tidak akan hilang dan tidak akan mengalami kematian selama-lamanya. ${ }^{32}$

Pada hakikatnya manusia dapat diikat oleh kuasa dosa dan tidak berkemampuan untuk melawan kuasa dosa dengan kekuatannya sendiri, sehingga

30 Sumiwi, "Gembala Sidang Yang Baik menurut Yohanes 10:1-18."

31 Polikarpus Ka'pan, "Kebangkitan Yesus Kristus Dasar Iman Kristen," Jurnal Jaffray 5, no. 1 (2007):

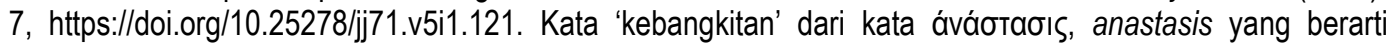
bangunnya berarti peningkatan status atau peningkatan kondisi seseorang; kebangkitan (dari mati). Kata áváotaбıs (anastasis) dari kata kerja anistemi yang berarti bangkit atau kata egeiro yang berarti bangun. (Lih.Sutanto, Perjanjian Baru Interlinear Yunani-Indonesia dan Konkordansi (PBIK) Jilid II, 2:602.)

32 Kata 'hidup' dalam frasa ini berarti menikmati keselamatan Tuhan atau hidup yang dapat dimengerti pada bagian ini bertalian erat dengan percaya dan mengandalkan kepada Tuhan. Kata 'hidup'

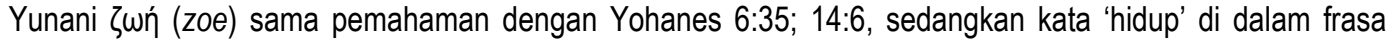

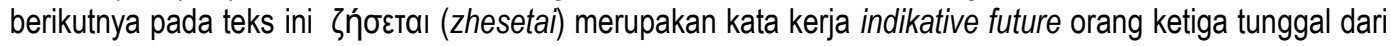

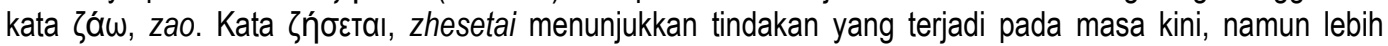

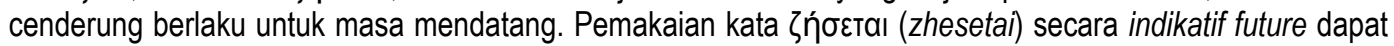
merujuk pada hidup yang berlaku untuk saat ini, tetapi berlaku juga untuk hidup pada masa mendatang yang dinyatakan oleh Yesus Kristus melalui kehidupan yang kekal. Kata $\zeta \omega(z 0)$ muncul sebanyak 140 kali dan dipakai lebih dahulu dalam kehidupan orang Kristen salah satu sebagai ciri keselamatan. (Lih. Laia, "Makna Injil Berdasarkan Roma 1: 16-17 Dan Implementasinya Bagi Gereja Masa Kini.") 
kematian dan kebangkitan Yesus menunjukkan bahwa Yesus lebih kuat dan lebih unggul untuk menang dari alam maut. Apabila setiap orang mengalami pembaruan hidup, maka pasti membenci dosa. Ka'pan menyatakan bahwa kebangkitan Yesus dapat dimengerti beberapa hal: Pertama, kebangkitan Yesus Kristus sebagai bukti mengalahkan setan dan Yesus memastikan kepastian untuk semangat dalam berkarya bagi-Nya; Kedua, kehidupan Yesus berarti setiap orang percaya dapat memulai hidup baru melalui persekutuan dengan Yesus secara terus-menerus; Ketiga, kehidupan Yesus dapat memberi harapan baru bagi setiap orang percaya untuk hidup bahagia bersama di Kerajaan-Nya yang abadi. ${ }^{33}$

Kehidupan Yesus dari mengalahkan maut dapat dilukiskan bahwa Yesus bangun dari antara orang mati, sehingga dapat menumbuhkan iman atau kepercayaan di dalam Dia sebab apabila Kristus tidak bangkit dari alam maut, maka sia-sialah kepercayaan umat manusia (bdk. 1 Kor. 15:17,18, 26). ${ }^{34}$ Kehidupan Yesus sangat bermakna bagi orang-orang yang percaya dan yang menerima kepada-Nya. Berdasarkan pemamaran di atas dapat simpulkan bahwa Yesus sebagai sumber kehidupan dan sumber utama untuk kebangkitan orang percaya.

\section{Akulah Jalan Dan Kebenaran Dan Hidup (Yoh. 14: 6)}

Pernyataan "Aku adalah jalan dan kebenaran dan hidup," terdiri atas tiga pemahaman yang sangat utama, yakni: Pertama, Akulah jalan dari kata Yunani

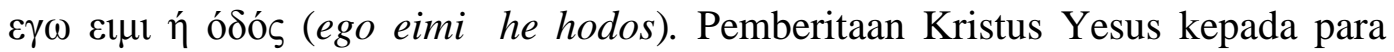
rasul-Nya yakni 'Akulah jalan,' bukan suatu ungkapan yang baru di pendengaran para murid, karena fondasinya telah tertulis dalam Perjanjian Lama. Kata 'jalan’

33 Ka'pan, "Kebangkitan Yesus Kristus Dasar Iman Kristen."

34 Harun Hadiwijono, Iman Kristen (Jakarta: BPK Gunung Mulia, 2007), 340. 
dalam Perjanjian Lama bertalian dengan Taurat (Torah), yakni bertalian dengan perintah, instruksi dan hukuman Allah (Ul. 4-6). ${ }^{35}$

Torah sebagai hukum Allah dalam Perjanjian Lama terdiri atas dua bagian besar. Pertama, Torah dari aliran Priest (Imam), sebab di dalam Kitab Imamat menyatakan tentang Torah Allah, yang bertalian dengan ritual ibadat atau spiritual. Sebagai contohnya ialah Torah persembahan bakaran (Im. 6: 2, 7, 18), Torah persembahan kesejahteraan (Im. 7: 1, 11), Torah persalinan perempuan (Im. 12: 7), Torah tentang penyakit kusta (Im. 13: 9; 14: 2, 32, 54), Torah tentang kecemburuan (Bil. 5: 29) dan Torah bagi orang bernazar (Bil. 6: 13, 21). Kedua, Torah dalam kitab Ulangan. Torah ini adalah perintah, instruksi, atau hukum Allah secara khusus mengenai hukum sosial masyarakat. Torah ini bertujuan untuk menolong manusia dari penindasan yang dilakukan oleh sesamanya atau oleh sistem yang ada. Sebagai contohnya ialah hukum tentang budak (Ul. 15: 1218, Kel. 21: 1-11), hukum tentang penculikan orang yang akan dijadikan budak (Kel. 21: 16, Ul. 23: 7), hukum tentang kreditur yang tidak boleh berbuat semenamena dengan bunga yang tinggi (Kel. 22: 25-26; Ul. 24: 6, 17), hukum lex talionis, yang merupakan hukum keadilan dalam konteks pengadilan, yakni tidak boleh bersaksi palsu (Ul. 10: 19, 14: 21 dan 29, 16: 11 dan 14, 24: 17, 19 dan 20). ${ }^{36}$ Dengan demikian, hukum Torah ini merupakan perintah Allah yang benar, suci, dan kudus. Hukum Torah ini disebut sebagai firman Allah dan Torah disebut sebagai jalan manusia datang kepada Allah.

${ }^{35}$ Kata ódós (hodos) berarti jalan; jalan raya; perjalanan; ajaran; jalan hidup (Lih.Sutanto, Perjanjian Baru Interlinear Yunani-Indonesia dan Konkordansi (PBIK) Jilid II, 2:522.). Moshe Weinfeld, "Deuteronomy 111. Anchor Bible 5," New York, 1991, 17-18.

36 Weinfeld, "Deuteronomy 1-11. Anchor Bible 5," 19-24. 
Pernyataan Yesus adalah jalan memiliki fondasi yang kuat dalam Perjanjian Lama. Yesus adalah pemberita jalan kepada Bapa sekaligus jalan tersebut (Yoh. 14: 1-14). Hendriksen mengatakan bahwa Yesus memang mengajarkan jalan tersebut (Mrk. 12: 14, Luk. 20: 21), menuntun orang percaya kepada jalan tersebut (Luk. 1: 79) dan mendedikasikan seluruh hidup-Nya kepada manusia, sehingga siapa yang berada di dalam jalan itu akan memeroleh kehidupan baru (Ibr. 10: 20). ${ }^{37}$ Jadi Yesus Kristus adalah jalan dari Allah kepada manusia sebab semua berkat datang dari Allah Bapa melalui Anak (Mat. 11: 27, 28) kemudian Yesus juga merupakan jalan dari manusia menuju kepada Allah.

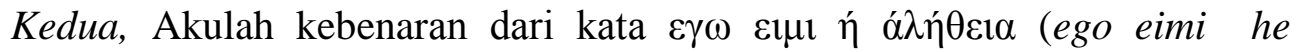
aletheia). Kata ó $\lambda \hat{\theta} \theta \varepsilon 1 \alpha$ (aletheia) yang artinya kebenaran; kejujuran. ${ }^{38}$ Dalam istilah Inggris disebut truth bukan right. Oleh karena istilah truth yang dipakai dalam teks ini, maka kata ini berarti kebenaran absolut atau kebenaran sejati. Kebenaran absolut hanya memiliki dua pemahaman yakni: (1) Allah Tritunggal merupakan kebenaran sejati yang disebut sebagai kebenaran subjek; (2) Firman Tuhan adalah kebenaran sejati yang berperan juga sebagai subjek tetapi menjadikan diri-Nya sebagai objek, sebab dibaca oleh setiap orang untuk menemukan jalan pikiran Allah, perasaan, dan karya-Nya. Yesus adalah pribadi yang benar-benar absolut dan tidak pernah berbuat salah serta dosa (bdk. 1Ptr. 2: 22). Kebenaran dalam teks ini menggunakan kata sandang $\eta$ (he), maka bukan kebenaran biasa, tetapi kebenaran yang luar biasa. Dengan demikian, kata kebenaran di dalam teks Yohanes 14: 6 tidak disebutkan bahwa Yesus hanya mengajarkan kebenaran tetapi justru Yesus menyatakan secara terus-menerus

37 William Hendriksen, New Testament Commentary: Exposition of the Gospel According to John, New Testament commentary (Grand Rapids: Baker Academic, 2007), 267.

38 Sutanto, Perjanjian Baru Interlinear Yunani-Indonesia dan Konkordansi (PBIK) Jilid II, 2:41. 
bahwa diri-Nya adalah kebenaran. Yesus Kristus dari Nazaret yang telah berinkarnasi, menderita, mati, bangkit, hidup dan naik ke Surga diberikan mandat penuh untuk menyelamatkan setiap orang yang percaya kebenaran Injil yang diajarkan oleh para pengajar Kristen melalui Alkitab.

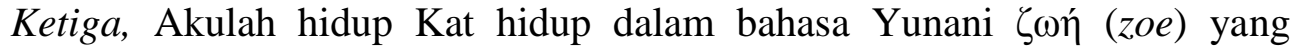
artinya hidup (kekal). ${ }^{39}$ Ungkapan hidup (zoe) dalam teks ini bukan hidup secara jasmani (bios) tetapi hidup yang dimaksudkan ialah hidup kekal. ${ }^{40}$ Hidup yang dimaksud bukanlah sebatas menghirup udara segar, berjalan, berlari, makan, minum dan bekerja. Ungkapan hidup di dalam teks Yohanes 14: 6 menggunakan kata sandang $\grave{\eta}(h e)$ yang menunjukkan pada hidup tidak secara temporal, namun hidup kekal. Dengan demikian saat Yesus menyatakan kepada para rasul tentang hidup menunjukkan jalan keselamatan yang kekal.

\section{Akulah Pokok Anggur yang benar (Yoh. 15: 1, 5)}

Ungkapan "Akulah pokok anggur yang benar," dalam bahasa Yunani 'E $\gamma \omega$

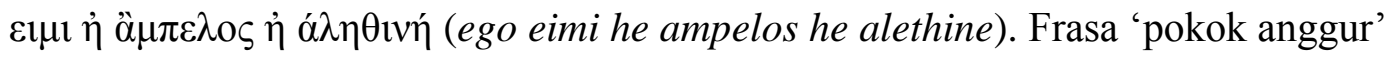
dalam bahasa Yunani ò $\mu \pi \varepsilon \lambda o \varsigma$ (ampelos) artinya pohon anggur. ${ }^{41}$ Dalam Injil Yohanes 15: 1 menunjukkan Yesus sebagai pokok dan orang Kristen sebagai

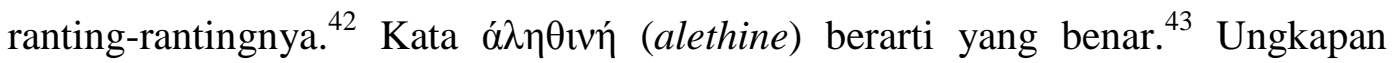
benar atau kebenaran menurut Kitab Injil Yohanes sebagai kebenaran Allah (bdk. Yoh. 3: 33), kebenaran Yesus (Yoh. 8: 26), Roh Kudus sebagai Roh kebenaran yang diutus oleh Bapa (Yoh. 15: 26), sehingga setiap orang percaya dipimpin

39 Hasan Sutanto, Perjanjian Baru Interlinear Yunani-Indonesia dan Konkordansi Perjanjian Baru Jilid 1, Jilid 1 (Jakarta, 2014), 555, 575.

40 Hendriksen, New Testament Commentary: Exposition of the Gospel According to John, 268.

41 Sutanto, Perjanjian Baru Interlinear Yunani-Indonesia dan Konkordansi Perjanjian Baru Jilid 1, 580.

42 W. R. F. Browning, Kamus Alkitab (Jakarta: BPK Gunung Mulia, 2019), 24.

43 Sutanto, Perjanjian Baru Interlinear Yunani-Indonesia dan Konkordansi Perjanjian Baru Jilid 1, 580. 
kepada seluruh kebenaran (Yoh. 16: 13). ${ }^{44}$ Kata sandang definit pada frasa pokok

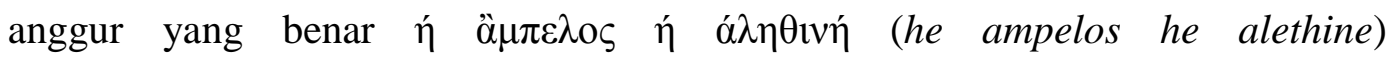
mengindikasikan bahwa pokok anggur yang benar adalah Yesus Kristus. Dalam perumpamaan ini Yesus menarasikan bahwa diri-Nya adalah pohon anggur yang benar dan orang-orang percaya merupakan ranting-ranting-Nya. Setiap orang yang telah percaya kepada Yesus harus terus-menerus memberi buah bahkan berbuah banyak tetapi kalau hidup di luar Yesus Kristus, maka tidak akan berbuat apaapa. ${ }^{45}$ Dengan demikian Yesus Kristus sebagai satu-satunya pokok kehidupan bagi orang percaya sehingga berbuah banyak dan menjadi model yang baik bagi sesama.

\section{Implikasi Bagi Umat Kristen}

Para pelayan Kristus Yesus mesti berperan aktif dalam memberikan pengajaran dan memproklamirkan kepada orang percaya bahwa Tuhan Yesus adalah Allah yang hidup dan telah membawa terang untuk dunia dan menyelamatkan umat manusia dari dosanya serta memberikan kelegaan rohani. ${ }^{46}$ Pribadi yang memberikan kepastian hidup adalah Kristus Yesus karena Dia adalah roti hidup. Kristus telah membawa terang bagi dunia sesuai mandat yang diberikan Allah Bapa kepada-Nya, melaksanakan misi-Nya, sehingga banyak orang yang menjadi pengikut Kristus hingga saat ini. Oleh karena Yesus adalah terang dunia, maka umat Tuhan mesti mengikuti pola kehidupan dan pelayananNya (bdk. Mat. 5: 13-14). Guthrie dkk menarasikan bahwa garam sangat

${ }^{44}$ Menurut Septuaginta (alethine) berarti benar dan sejati (Lih. Emanuel Gerrit Singgih, "Rantingranting dari Pohon Kehidupan: Pemahaman Alkitab mengenai Yohanes 15: 1-10," Gema Teologi 33, no. 1

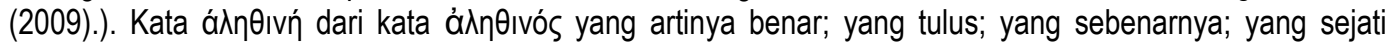
(Lih.Sutanto, Perjanjian Baru Interlinear Yunani-Indonesia dan Konkordansi (PBIK) Jilid II, 2:42.). Browning, Kamus Alkitab, 55.

45 Stamps, Alkitab Penuntun Hidup Berkelimpahan, 1735.

46 Guthrie, Motyer, dan Stibbs, Tafsiran Alkitab Masa Kini 3 Matius-Wahyu, 287. 
berfaedah untuk mengawetkan makanan. ${ }^{47}$ Sedangkan terang berfaedah untuk menerangi kegelapan. Pemahaman soal garam dan terang merupakan tindakan hidup nyata yang membangun orang lain mesti diekspresikan oleh umat Tuhan. Hidup dan perkataan yang bijaksana dari para rasul akan memengaruhi masyarakat tetapi perhubungan dengan masyarakat tanpa menjadi tawar adalah perlu diperioritaskan dalam kehidupan sehari-hari. Umat Tuhan perlu menjadi terang bagi dunia (bdk. Rm. 2: 19; Flp. 2: 15). ${ }^{48}$

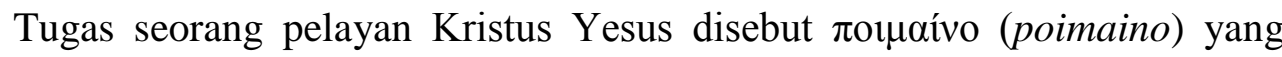
berarti menggembalakan; memerintah dan mementingkan. ${ }^{49}$ Menggembala secara figuratif mempunyai arti memimpin, menuntun dan melindungi. ${ }^{50}$ Pelayan Kristus Yesus harus berperan sebagai gembala untuk mengasihi, peduli, dan membangun kerohanian bagi domba-dombanya. Domba-domba diibaratkan sebagai umat Tuhan yang harus dilayani secara baik dan benar, supaya karakter hidup mereka sama seperti Kristus. Yesus Kristus memiliki karakter yang benar, yang ditunjukkan kepada para pengikut-Nya pada masa dulu. Yesus sebagai gembala yang benar selalu bertanggung jawab dalam mencari dan menemukan domba-domba (umat-Nya) yang hilang (bdk. Luk 19: 10). ${ }^{51}$ Yesus menunjukkan diri-Nya sebagai gembala yang benar dalam menuntun umat-Nya supaya hidup bersama dan bertumbuh di dalam Dia. Pelayan Kristus Yesus perlu menggembalakan umat-Nya dengan hati yang tulus berarti setia dalam pelayanan penggembalaan supaya umat-Nya bertumbuh kerohanian dengan baik. Pelayanan

47 Guthrie, Motyer, dan Stibbs, 71.

48 Guthrie, Motyer, dan Stibbs, 71.

49 Sutanto, Perjanjian Baru Interlinear Yunani-Indonesia dan Konkordansi (PBIK) Jilid II, 2:614.

50 Sutanto, Perjanjian Baru Interlinear dan Konkordansi Jilid 2, 614.

51 Ibelala Gea, "Kepemimpinan Yesus Teladan Pemimpin Masa Kini," Voice of Wesley: Jurnal IImiah Musik dan Agama 3, no. 2 (2020): 29-40, https://doi.org/10.36972/jvow.v3i2.52. 
penggembalaan sangatlah penting karena tanpa penggembalaan, maka umat-Nya akan tercerai-berai. Seorang pelayan Kristus Yesus dalam memberikan pengajaran mesti berpedoman pada firman Tuhan.

Yesus sebagai gembala yang benar pernah mengorbankan nyawa-Nya bagi manusia yang telah hilang kemuliaan Allah karena dosa. ${ }^{52}$ Gembala yang benar (bdk. Mzm. 23: 1-6) telah menanggung dosa manusia hingga mati di kayu salib. Para pelayan Kristus mengajarkan pengajaran sehat kepada umat Tuhan supaya umat-Nya tidak mempraktikkan pengajaran sesat dan membawa umat-Nya keluar dari ajaran sesat ketika umat-Nya telah tersesat/disesatkan gembala palsu. Dalam pengajaran Kristen bahwa sesungguhnya para gembala jemaat perlu loyal dalam menggembalakan umat Tuhan karena panggilan sebagai gembala adalah panggilan dari Yesus Kristus. Gembala yang benar atau gembala agung (Ibr. 13:20) memberikan nyawanya bagi domba-dombanya atau umat-Nya. Yesus selama melayani orang banyak pada masa itu tidak mengajarkan jalan baru di dalam diri orang lain untuk kehidupan kekal kepada para pendengar-Nya tetapi justru Dia adalah jalan menuju hidup kekal. Jadi Kristus Yesus sebagai jalan kehidupan dan pintu menuju kehidupan kekal bagi orang-rang yang mengasihiNya.

\section{KESIMPULAN}

Yohanes menarasikan tujuh pernyataan ego eimi dari ucapan Yesus bahwa Yesus sebagai Allah. Akulah roti hidup, Akulah terang dunia, Akulah Pintu, Akulah gembala yang baik, Akulah kebangkitan dan hidup, Akulah jalan dan

52 William Barclay, Pemahaman ALkitab Setiap Hari Injil Matius Pasal 11-28 (Jakarta: BPK Gunung Mulia, 2010), 86. 
kebenaran dan hidup dan Akulah Pokok Anggur yang benar. Ego eimi adalah pernyataan sakral Tuhan Yesus untuk meyakinkan kepada para murid tentang eksistensi-Nya sebagai Allah yang hidup. Pemahaman tentang ego eimi memberikan pengaruh dalam mengenal pribadi dan karya dari Yesus Kristus, sehingga semakin memperkuat dasar iman umat Kristen dalam memproklamirkan Kabar Baik.

\section{DAFTAR PUSTAKA}

Barclay, William. Pemahaman ALkitab Setiap Hari Injil Matius Pasal 11-28. Jakarta: BPK Gunung Mulia, 2010.

Blum, Edwin A. "John. The Bible Knowledge Commentary." Wheaton, IL: Victor Books, 1985.

Brickner, David. Christ in the Feast of Tabernacles. Chicago, Illinois: Moody Publishers, 2006.

Browning, W. R. F. Kamus Alkitab. Jakarta: BPK Gunung Mulia, 2019.

G. R. Beasley Murray. John Volume 36. Dallas, Texas: Word Books, Publisher, 2002.

Gea, Ibelala. "Kepemimpinan Yesus Teladan Pemimpin Masa Kini." Voice of Wesley: Jurnal Ilmiah Musik dan Agama 3, no. 2 (2020): 29-40. https://doi.org/10.36972/jvow.v3i2.52.

Gulo, Arif Yupiter. "Cerdik seperti Ular dan Tulus seperti Merpati: Berdasarkan Matius 10:16b.” Manna Rafflesia 7, no. 1 (31 Oktober 2020): 116-34. https://doi.org/10.38091/man_raf.v7i1.129.

Guthrie, Motyer, dan Stibbs. Tafsiran Alkitab Masa Kini 3 Matius-Wahyu. Jakarta: YAyasan Bina KAsih/OMF, 2001.

Hadiwijono, Harun. Iman Kristen. Jakarta: BPK Gunung Mulia, 2007.

Harrison, F. Evertt. John The Gospel of Faith. Chicago: Moody Press, 1962.

Hendriksen, William. New Testament Commentary: Exposition of the Gospel According to John. New Testament commentary. Grand Rapids: Baker Academic, 2007. 
Ka'pan, Polikarpus. "Kebangkitan Yesus Kristus Dasar Iman Kristen.” Jurnal Jaffray 5, no. 1 (2007): 7. https://doi.org/10.25278/jj71.v5i1.121.

Laia, Kejar Hidup. "Makna Injil Berdasarkan Roma 1: 16-17 Dan Implementasinya Bagi Gereja Masa Kini." Manna Rafflesia 7, no. 1 (2020): 1-21. https://doi.org/10.38091/man_raf.v7i1.133.

Lilo, Deflit Dujerslaim. "Presuposisi dan Metode Yesus dalam Menyampaikan Pendapat: Sebuah Pedoman bagi Para Akademisi." BIA': Jurnal Teologi dan Pendidikan Kristen Kontekstual 2, no. 1 (26 Juni 2019): 121-38. https://doi.org/10.34307/b.v2i1.86.

Marisi, Candra Gunawan. "Analisis Teologis Mengenai Tugas Dan Tanggungjawab Gembala Yang Baik Menurut Yohanes 10: 1--18 Dan Penerapannya Bagi Gembala Masa Kini." Real Didache Jurnal Teologi dan Pendidikan Agama Kristen 4, no. 2 (2019): 46.

Morris, Leon. Teologi Perjanjian Baru. Malang: Gandum Mas, 2014.

Nugroho, Daniel. "Mengulas Lengkap Siapa Pribadi Yesus." Www.danielnugroho.com. Faith, $\quad 9 \quad$ Januari 2021. https://www.danielnugroho.com/faith/mengulas-lengkap-siapa-pribadiyesus/.

Singgih, Emanuel Gerrit. "Ranting-ranting dari Pohon Kehidupan: Pemahaman Alkitab mengenai Yohanes 15: 1-10.” Gema Teologi 33, no. 1 (2009).

Stamps, Donald C. Alkitab Penuntun Hidup Berkelimpahan. Jakarta: Lembaga Alkitab Indonesia, 2008.

Sumiwi, Asih Rachmani Endang. "Gembala Sidang Yang Baik menurut Yohanes 10:1-18.” HARVESTER: Jurnal Teologi dan Kepemimpinan Kristen 4, no. 2 (2020): 74-93. https://doi.org/10.52104/harvester.v4i2.16.

Sutanto, Hasan. Perjanjian Baru Interlinear dan Konkordansi Jilid 2. Jakarta: Lembaga Alkitab Indonesia, 2014.

-. Perjanjian Baru Interlinear Yunani-Indonesia dan Konkordansi Perjanjian Baru Jilid 1. Jilid 1. Jakarta, 2014.

Weinfeld, Moshe. "Deuteronomy 1-11. Anchor Bible 5." New York, 1991, 22630.

Zaluchu, Sonny Eli. "Strategi Penelitian Kualitatif dan Kuantitatif Di Dalam Penelitian Agama." Evangelikal: Jurnal Teologi Injili dan Pembinaan Warga Jemaat 4, no. 1 (2020): 28-38. https://doi.org/10.46445/ejti.v4i1.167. 